\title{
Methyl Salicylate Affects the Quality of Hayward Kiwifruits during Storage at Low Temperature
}

\author{
Morteza Soleimani Aghdam (Corresponding author) \\ Department of Horticultural Science, Faculty of Agriculture, University of Tabriz, Tabriz, Iran \\ Iranian Young Researchers Club, Islamic Azad University, Ahar Branch, Ahar, Iran \\ Tel: 98-914-759-8795_E-mail: Aghdam_1361@yahoo.com \\ Alireza Motallebiazar \\ Department of Horticultural Science, Faculty of Agriculture, University of Tabriz, Tabriz, Iran
}

Tel: 98-914-401-9637Ｅ-mail: Motallebiazar@gmail.com

Younes Mostofi

Department of Horticultural Science, University College of Agriculture and Natural Resources

University of Tehran, Tehran, Iran

Tel: 98-912-501-0492Ｅ-mail: ymostofi@ut.ac.ir

Javad Fattahi Moghaddam

Iran Citrus Research Institute, Ramsar

Tel: 98-911-392-8044Ｅ-mail: fattahi80@yahoo.com

Mahmood Ghasemnezhad

Departments of Horticultural Science, Faculty of Agriculture, University of Guilan, Rasht, Iran Tel: 98-426-223-4857Ｅ-mail: Ghasemnezhad@Guilan.ac.ir

Received: October 22, 2010 Accepted: November 9, $2010 \quad$ doi:10.5539/jas.v3n2p149

The research is financed by Department of Horticultural Science, Faculty of Agriculture, University of Tabriz, Tabriz, Iran

\begin{abstract}
Hayward kiwifruit were treated with methyl salicylate (MeSA) at different concentrations $(0,8,16,24,32$ $\left.\mu \mathrm{L} . \mathrm{L}^{-1}\right)$, then stored at $0.5^{\circ} \mathrm{C}$ and $90 \% \mathrm{RH}$ for 5 months to investigate postharvest quality and ripening behavior. MeSA treatments, especially at $32 \mu \mathrm{L} . \mathrm{L}^{-1}$ concentrations, were highly effective in reducing ethylene production, fungal decay, APX and CAT activity, weight loss and total soluble solids (TSS) in Hayward kiwifruit, as well as ascorbic acid (AA) and flesh firmness loss compared with that observed in control fruit. Hayward kiwifruit treated with $24 \mu \mathrm{L} . \mathrm{L}^{1}$ MeSA was lowest $\mathrm{pH}$. Titrable acidity (TA) of the Hayward kiwifruit was not significantly affected by the use of MeSA treatments.
\end{abstract}

Keywords: Ascorbic acid, Ethylene, Fungal decay, Kiwifruit, Methyl salicylate

\section{Introduction}

Kiwifruits (Actinidia deliciosa) are an interesting product specially in recent years due to its high level of vitamin $\mathrm{C}$ and its strong antioxidant capacity due to a wide number of phytochemicals including carotenoids, phenolics, flavonoid, and chlorophyll (Cassano et al., 2006). Based on these characteristics, kiwifruits offer 
benefits for specific health conditions and has a great potential for industrial exploitation (Cano Pilar, 1991). Nowadays, kiwifruit is an important fruit produced in commercial scale in Iran. Kiwifruit from all growing areas may deteriorate due to infection by Botrytis cinerea, which causes Gray Mold decay (Snowdon, 1990). To reduce postharvest decay of fruits, it is necessary to improve plant defense mechanism and to decrease fungi contamination during plant vegetative growth, flowering, fruit development and postharvest stages.

Salicylic acid (SA) and methyl salicylate (MeSA) are endogenous signal molecules, playing pivotal roles in regulation stress responses and plant development including heat production, disease resistance, seed germination, sex polarization and ethylene production (Asgharia and Aghdam, 2010; Aghdam et al., 2009). SA mediated hypersensitive and systemic acquired resistances (SAR) against pathogen attack proposed to be mediated through the inhibition of catalase (CAT) and Ascorbate peroxidase (APX) activity, which subsequently raises intra-cellular $\mathrm{H}_{2} \mathrm{O}_{2}$ concentration. This increased intra-cellular $\mathrm{H}_{2} \mathrm{O}_{2}$ concentration proposed to act as a second messenger in activation and expression of defense related genes (Raskin, 1992). The SA induced defense responses are probably involved in the expression of a range of defense genes, especially those encoding PR-proteins such as phenylalanine ammonia lyase (PAL), chitinase, $\beta-1,3$-glucanase and peroxidase (POD) (Meena et al., 2001). In addition, SA exhibit antifungal effects on harvested fruits (Amborabe et al., 2000). Moreover, dietary salicylates from fruit and vegetables are described as bioactive compounds with health care potential and considered as generally recognized as safe (GRAS) (Hooper and Cassidy, 2006). SA and MeSA are known as inhibitors of ethylene biosynthesis (Leslie and Romani, 1986) and reported to inhibit wound induced transcription of ACC synthase expression and activity in tomato fruit (Li et al., 1992). SA can delay the ripening of banana fruit, probably through inhibition of ethylene biosynthesis or action (Srivastava and Dwivedi, 2000). Fan et al (1996) demonstrated the inhibitory action of SA on ACC Oxidase activity in apple fruit disks. Babalar et al (2007) reported that $2 \mathrm{mmol}^{-1} \mathrm{SA}$ significantly reduced ethylene production and fungal decay and retained overall quality of Selva strawberry fruit. Treatment of banana seedling with $0.5 \mathrm{mM}$ SA reduced CAT and APX activity and enhanced chilling tolerance (Kang et al., 2003). Chan and Tian (2006) reported that SA treatment significantly inhibited CAT activity in sweet cherry fruit. Wang et al (2006) reported that treatment with SA was effective in alleviating chilling injury of peach fruit. This author suggested that the effect of SA on alleviating chilling injury of peaches during cold storage may be attributed to its ability to induce antioxidant systems and heat shock proteins (HSPs). This study was carried out to investigate the effects of several MeSA concentrations on fungal decay in relation with CAT and APX activity, quality attributes such as ascorbic acid (AA) content, flesh firmness, total soluble solids (TSS), titrable acidity (TA), $\mathrm{pH}$, weight loss and ethylene production in kiwifruit during postharvest storage.

\section{Material and methods}

\subsection{Sample preparation}

Uniform size fruit of kiwifruit (Actinidia deliciosa cv. Hayward) harvested at commercial maturity from an orchard in Citrus Research Institute in Ramsar-Iran and transferred to the laboratory on the same day. Fruit divided into five groups of 300s, comprising three replicates of 100. For MeSA vapor treatments, fruit were placed in 300-1 air-tight containers, together with MeSA spotted onto filter paper at the final concentration of 0 (control), 8, 16, 24 and $32 \mu \mathrm{L} . \mathrm{L}^{-1}$, respectively, followed by incubation for $16 \mathrm{~h}$ at $20^{\circ} \mathrm{C}$. After these treatments the containers were opened, ventilated, and stored at $0.5{ }^{\circ} \mathrm{C}$ and $90 \% \mathrm{RH}$. Evaluation was carried out for the periods of 5 months with 30 days intervals. Quality attributes such as ascorbic acid (AA) content, flesh firmness, total soluble solids (TSS), titrable acidity (TA), weight loss, ethylene production and antioxidant enzymes activity, CAT and APX evaluated during storage at $0.5^{\circ} \mathrm{C}$ and $90 \% \mathrm{RH}$.

\subsection{Quality attributes analysis}

Fruit ethylene production was determined following the method of Zhang et al (2003) with some modifications. Occurring this, five fruits were placed in a $1 \mathrm{~L}$ flask, capped with a rubber stopper for $1 \mathrm{~h}$. Head space samples $(1 \mathrm{ml})$ were collected by syringe and ethylene concentrations measurement by a GC (Shimadzu, GC-14A, Japan) apparatus. Ascorbic acid content measured by titration against 2, 6-dichloro-indophenol (AOAC, 1990) and results were expressed as mg of Ascorbic acid per $100 \mathrm{~g}$ of fresh weight (mg/100 g FW). Flesh firmness measured using a fruit pressure tester FT-011 (Facchini, Italy) on five individual fruit at each replicate by measuring force required for an $8 \mathrm{~mm}$ probe to penetrate in two opposite locations the mesocarp tissue. Titrable acidity was measured using titration method. To do that, $5 \mathrm{~mL}$ fruit juice was added to $25 \mathrm{~mL}$ distilled water plus two drops of phenolphthalein and titrated with $0.1 \mathrm{~N} \mathrm{NaOH}$ up to $\mathrm{pH} 8.1$. The results were expressed as $\mathrm{g}$ of citric acid per $100 \mathrm{~g}$ fresh weight. TSS was determined using ATAGO-ATC-20E (Japan) refractometer at $20{ }^{\circ} \mathrm{C}$ and expressed as ${ }^{\circ} \mathrm{Brix}$. The $\mathrm{pH}$ of fruit juice was measured using a Jenway $3320 \mathrm{pH}$ meter. In order to determine 
any weight loss during the storage of the fruit, both treated and untreated fruits were weighted 1, 2, 3, 4 and 5 month after treatments.

\subsection{Fruit fungal decay (DI)}

Fruit decay was assessed at the end of storage life, by using 30 fruit per replicate. According to the amount of the fungal mold on fruit surface scales from 1 to 5 were given to the each treatment group where; $1=$ normal (no decay on fruit surface), 2 = trace (up to $5 \%$ fruit surface were decayed), $3=$ slight $(5-20 \%$ of fruit surface were decayed), $4=$ moderate $(20-50 \%$ fruit surface were decayed $)$, and $5=$ severe $(>50 \%$ of fruit surface were decayed). From this, a decay index (DI) was expressed as: DI index $=\sum[(\mathrm{DI}$ level $) \times($ number of fruit at the DI level)] / ( $4 \times$ total number of fruit in the treatment).

\subsection{Ascorbate peroxidase (APX) and Catalase (CAT) activity}

APX activity assayed according to the method of Jimenez et al., (1997). Approximately $5 \mathrm{~g}$ of frozen fruit were ground with $16 \mathrm{ml}$ of extraction buffer (100 mM sodium phosphate $\mathrm{pH} 7.0 ; 0.1(\mathrm{v} / \mathrm{v})$ Triton X-100; $1 \mathrm{M} \mathrm{NaCl}$; $\left.10 \mathrm{~g} \mathrm{l}^{-1} \mathrm{PVPP}\right)$ using an omnimixer. The suspension was stirred for $1 \mathrm{~h}$ and then centrifuged at $10,000 \times \mathrm{g}$ for $10 \mathrm{~min}$. The resulted supernatant later was used for assaying the enzyme activity under $0-4{ }^{\circ} \mathrm{C}$ condition. The activity was assayed at $30^{\circ} \mathrm{C}$ in a mixture containing $100 \mathrm{mM}$ sodium phosphate buffer $\mathrm{pH} 7.0 ; 2 \mathrm{mM}$ ascorbic acid; $4 \mathrm{mM} \mathrm{H}_{2} \mathrm{O}_{2}$ and $500 \mu \mathrm{l}$ of enzymatic extract in a final volume of $3.0 \mathrm{ml}$. The reduction in absorbance at $290 \mathrm{~nm}$ was measured. One unit of enzyme activity was defined as the amount of enzyme that can oxidize 1 $\mu$ mol of ascorbate at $25^{\circ} \mathrm{C}$ for $1 \mathrm{~min}$. CAT activity was assayed according to the method of Chance and Maehly (1954). Approximately $5 \mathrm{~g}$ of frozen fruit were ground with $0.1 \mathrm{~g}$ PVPP and followed by addition of $10 \mathrm{ml}$ of extraction buffer (74 mg DTT; $1.2 \mathrm{~g}$ PEG 4000 and $2.4 \mathrm{ml}$ EDTA $10 \mathrm{mM}$ in $240 \mathrm{ml}$ phosphate buffer $0.1 \mathrm{M}$, pH 7.8). The suspension later was stirred for $1 \mathrm{~h}$ and then centrifuged at $20,000 \times \mathrm{g}$ for $15 \mathrm{~min}$. The resulted supernatant was used for assaying the enzyme activity under $0-4{ }^{\circ} \mathrm{C}$ condition. The activity was assayed in a mixture containing $31.8 \mu \mathrm{l} \mathrm{H}_{2} \mathrm{O}_{2} 30 \%$ in $10 \mathrm{ml}$ of phosphate buffer $0.1 \mathrm{M} \mathrm{pH} 7\left(5.44 \mathrm{~g} \mathrm{KH}_{2} \mathrm{PO}_{4}\right.$ in $400 \mathrm{ml} \mathrm{H}_{2} \mathrm{O}$ mixing with $10.46 \mathrm{~g} \mathrm{~K}_{2} \mathrm{HPO}_{4}$ in $600 \mathrm{ml} \mathrm{H}_{2} \mathrm{O}$ unit $\mathrm{pH}$ 7) and $10 \mu \mathrm{l}$ of enzymatic extract. The reduction of absorbance at $240 \mathrm{~nm}$ was measured. One unit of enzyme activity was defined as the amount of the enzyme catalyzing the decomposition of $1 \mu \mathrm{mol} \mathrm{H}_{2} \mathrm{O}_{2}$ per min at $30^{\circ} \mathrm{C}$.

\subsection{Statistical analysis}

Data from the analytical determinations were subjected to analysis of variance (ANOVA). Mean comparisons were performed using Duncan's test $(P<0.05)$. All analyses were performed with SPSS software package.

\section{Results and Discussion}

\subsection{Quality attributes}

As shown in Table. 1, ethylene production of the kiwifruit was significantly decreased by treating with MeSA (P $<0.01$ ). Control fruit had the highest rate of ethylene production at all evaluation times, while the lowest rate of ethylene production occurred in $32 \mu \mathrm{L} . \mathrm{L}^{-1}$ treatment. In other hand, ethylene production in fruit decreased with increasing of MeSA concentration and the most effective MeSA concentration was $32 \mu \mathrm{L} . \mathrm{L}^{-1}$. Ethylene plays a key role in fruit ripening and senescence. This hormone triggers the induction of cell wall hydrolyzing enzymes leading to increase in respiration rate, fruit softening and senescence (Wills et al., 1998). In this study, MeSA treatment significantly decreased ethylene production in Hayward kiwifruits. Both SA and ASA have been shown to inhibit ethylene production in cultured pear cells, mung bean hypocotyls, apple and pear fruit tissue discs, carrot cell suspension cultures and strawberry fruit (Babalar et al., 2007; Romani et al., 1989). Srivastava and Dwivedi (2000) reported that SA has delayed the ripening of banana fruit, probably through inhibition of ethylene biosynthesis or action. SA decreases ethylene production by decreasing ACS and ACO production and activity (Asgharia and Aghdam, 2010). Zhang et al (2003) reported that postharvest treatment of kiwifruit with acetyl salicylic acid (ASA) resulted in a lower ACO and ACS activity and decreased ethylene production during the early stages of fruit ripening. MeSA treatment maintained firmness of fruit flesh significantly $(\mathrm{P}<0.01$; Table 2) during storage. There was a positive correlation between MeSA concentration and fruit firmness. The highest fruit firmness was observed when $32 \mu \mathrm{L} . \mathrm{L}^{-1}$ MeSA applied at all determination times, while the lowest rate of firmness was related to control fruits. Softening of fruits is a main and critical quality changes during storage. In this study, MeSA, in a concentration dependent manner from 0 to $32 \mu \mathrm{L}^{-1}$, maintained firmness of kiwifruit during storage. Srivastava and Dwivedi (2000) reported that when bananas treated with SA, fruit softening markedly decreased. Zhang et al (2003) reported a positive correlation between fruit free SA content and firmness in kiwifruit during ripening. It has been demonstrated that SA decreased ethylene production and 
inhibited cell wall and membrane degrading enzymes leading to decreasing the fruit softening rate (Srivastava and Dwivedi, 2000; Zhang et al., 2003).

As shown in Table 3, TSS increased during postharvest storage and MeSA treatment significantly affected TSS $(P<0.05)$. The most effective MeSA concentration was $32 \mu \mathrm{L} . \mathrm{L}^{-1}$ and of $14.8 \%$ in control fruit received to $13.5 \%$ in fruits treated with $32 \mu \mathrm{L} . \mathrm{L}^{-1}$. As seen in Table $3, \mathrm{pH}$ of fruit juice increased after 3 month of storage beginning but then decreased to end of storage. MeSA treatment significantly affected $\mathrm{pH}(P<0.05)$. pH of fruits who treated with $24 \mu \mathrm{L} . \mathrm{L}^{-1}$ was 3.52 , while in control fruit was 3.40 . Generally, pH of control fruits increased during postharvest storage, but those treated by MeSA were decreased. Titrable acidity was not significantly affected by using of MeSA treatments. TSS and soluble sugars may increase during fruit ripening due to the action of sucrose-phosphate synthase (SPS), a key enzyme in sucrose biosynthesis (Hubbard et al., 1991). This enzyme is activated by the ripening process, ethylene, and cool storage (Langenkämper et al., 1998). Recently, an increase in SPS and invertase activities and a decrease in sucrose synthase activity have been reported during ripening of some fruits (Cordenunsi and Lajolo, 1995). In this study treatment of kiwifruits with MeSA (32 $\left.\mu \mathrm{L} . \mathrm{L}^{-1}\right)$ maintained a lower content of TSS than the control fruits at the end of cold storage. We propose that MeSA reduced ethylene production may results to decreased SPS enzyme activity leading to decrease in sucrose synthesis and TSS content. Cell walls contain large amounts of polysaccharides, mainly pectins and cellulose, and are digested due to the activity of the cell wall degrading enzymes leading to a significant increase in TSS content. SA effectively protects cell walls by decreasing the expression of degrading enzymes and as a consequence prevents from dramatic increase in TSS content of the cells (Asghari and Aghdam, 2010).

Weight loss of the kiwifruit was significantly decreased when they were treated by MeSA $(P<0.01$; Table 2$)$. Control fruits had the highest of weight loss at all determination times, while the lowest of weight loss occurred in $32 \mu \mathrm{L} . \mathrm{L}^{-1}$ MeSA concentration. In additional, weight loss in fruit decreased with increasing of MeSA concentration. It has been demonstrated that SA in a concentration dependent manner effectively reduces respiration in plants and harvested fruits (Srivastava and Dwivedi, 2000; Han et al., 2003; Wolucka et al., 2005). Decrease in fruit metabolic activities results to decrease in fruit water content, weight loss, carbohydrate depletion rate and consequently, effectively delays fruit senescence process (Wills et al., 1998). In this study kiwifruit treated with $32 \mu \mathrm{L} . \mathrm{L}^{-1}$ MeSA had the lowest weight loss during postharvest storage and was negative correlation between concentration of MeSA and weight loss in storage. During storage, MeSA treatment maintained significantly $(\mathrm{P}<0.01$; Table. 2) ascorbic acid content of the fruit being a positive correlation between MeSA concentration and fruit ascorbic acid content. The highest ascorbic acid content was observed in fruit treated with $32 \mu \mathrm{L} . \mathrm{L}^{-1}$ at all determination times, while the lowest ascorbic acid content was related to control fruits. Ascorbate (AA), as an essential metabolite and powerful regulator of cell functions, play a critical role in antioxidant defense system (Smimoff, 1995). In our work, AA content in MeSA treated fruit were higher than that control fruits. Hung et al (2007) suggested that high AA contents in the pulp of pretreated fruit with SA may result from an acceleration of biosynthetic pathways or a decrease in catabolism through an accumulation of dehydroascorbate (DHAA). Accumulation of DHAA suggests that catabolism may be an important reason for this. Both changes lead to a shift from the reduced form to the oxidized form, to a decrease in the AA/DHAA ratios. In grape plants, salicylic acid enhanced $\mathrm{PM}-\mathrm{Ca}^{2+}-\mathrm{ATPase}$ and $\mathrm{V}-\mathrm{Ca}^{2+}$-ATPase activity and induced $\mathrm{Ca}^{2+}$ movement from vacuoles and intercellular spaces to the cytoplasm, higher cytosolic $\mathrm{Ca}^{2+}$ might induce the Ascorbate-Glutathione cycle (GR activity increased and high GR activity maintains the pool of GSH, allowing GSH to be used by DHAR to reduced DHA to AA), causing GSH and AA to increase and salicylic acid pretreated plants maintaining higher AA/DHAA and GSH/GSSG rate (Wang and Li, 2006). Hung et al (2007) reported that activities of GR and DHAR and the content of AA and GSH in Cara cara navel orange during fruit storage declined but the SA-pretreatment reduced the rate of this decline and the SA-pretreated fruit had higher values of AA/DHAA and GSH/GSSG than those in controls.

\subsection{Fruit fungal decay (DI), CAT and APX activity}

DI was significantly ( $\mathrm{P}<0.01$; Table. 3 ) affected by MeSA vapor in the end of shelf life period so that DI in the fruits treated with $32 \mu \mathrm{L} . \mathrm{L}^{-1}$ MeSA were $6.3 \%$ whereas it was $34.2 \%$ in control fruits. CAT and APX activity gradually increased during storage while their activity were significantly $(\mathrm{P}<0.01$; Table 4$)$ reduced in MeSA treated fruit. The lowest CAT and APX activity observed when $32 \mu \mathrm{L} . \mathrm{L}^{-1} \mathrm{MeSA}$ applied at all determination times, while the highest CAT and APX activity was related to control fruits. In totally, CAT and APX activity in fruit decreased with MeSA concentration increased especially in $32 \mu \mathrm{L} . \mathrm{L}^{-1} \mathrm{MeSA}$ concentration. Exogenous application of SA at nontoxic concentrations to susceptible fruits and vegetables could enhance resistance to pathogens and control postharvest decay (Asgharia and Aghdam, 2010; Aghdam et al., 2009). SA in a 
concentration dependent manner from 1 to 2 mmol L$^{-1} 1$ effectively reduced fungal decay in Selva strawberry fruit (Babalar et al., 2007). MeSA triggers disease resistance and mediates the expression of defense related genes in neighboring plants and in healthy tissue of infected plants (Shulaev et al., 1997). Hayward kiwifruit postharvest decay was significantly affected by MeSA vapor at the end of storage period. Decay incidence in fruit treated with $32 \mu \mathrm{L} . \mathrm{L}^{-1}$ was $6.3 \%$ whereas it was $34.2 \%$ in control fruits. Dipping of pear fruit in $1 \mathrm{mmol} \mathrm{L}^{-1} \mathrm{SA}$ solution effectively controlled fruit decay during 5 months of cold storage (Asghari et al., 2007). Postharvest treatment of table grapes with SA before coating with chitosan significantly enhanced the efficiency of coating and decreased fruit decay (Asghari et al., 2009). SA also exhibits direct antifungal effects against pathogens. $2 \mathrm{mmol} \mathrm{L}^{-1} \mathrm{SA}$ showed direct fungal toxicity on Monilinia fructicola and significantly inhibited the mycelia growth and spore germination of the pathogen in in vitro (Yao and Tian, 2005). According to the results of Qin et al (2003), 0.5 mmol L ${ }^{-1}$ SA significantly reduced the incidence of blue mould (P. expansum) and alternaria rot (A. alternata) in sweet cherry without any surface injury. Adding SA significantly improved the activity of $R$. glutinis against both pathogens. Qin et al (2003) demonstrated that SA treatment can stimulate the synthesis of antioxidant enzymes in sweet cherry fruit and induces a significant increase in the activities of polyphenoloxidase (PPO), phenylalanine ammonia lyase (PAL) and $\beta-1,3$-glucanase. Zeng et al (2006) suggested that PAL and $\beta-1$, 3-glucanase, as well as $\mathrm{H}_{2} \mathrm{O}_{2}$ or $\mathrm{O}_{2}^{-}$, may be involved in the enhancement of disease resistance in mangoes. Kiwifruit treatment with MeSA resulted in a significant decrease in fungal decay confirming the fact that MeSA leads to the activation of plant defense system against pathogens. Pretreatment of kiwifruit with MeSA reduce CAT and APX activity and negative correlation exist between MeSA concentration and CAT and APX activities. The lowest CAT and APX activity was observed when $32 \mu \mathrm{L} . \mathrm{L}^{-1}$ MeSA applied at all determination times, while the highest activities of CAT and APX were related to controls.

\section{Conclusions}

In conclusion, the role of MeSA in reducing postharvest decay in Hayward kiwifruit has been addressed. From the assayed concentrations, $32 \mu \mathrm{L} . \mathrm{L}^{-1}$ as the most effective for reducing CAT and APX activity and DI, ethylene production, weight loss, TSS and for maintenance of AA levels and flesh firmness. However, more in-depth experiments should be carried out to understand the mechanism by witch MeSA improves the postharvest quality of Hayward kiwifruit.

\section{References}

Amborabe, B.E., Lessard, P.F., Chollet, J.F., \& Roblin, G. (2000). Antifungal effects of salicylic acid and other benzoic acid derivatives towards Eutypa lata: Structure-activity relationship. Plant Physiol Biochem, 40, 1051-1060.

AOAC. (1990). Official methods of analysis of the Association of Official Analytical Chemists. $15^{\text {th }}$ ed., Association of Official Analytical Chemists, Arlington VA, pp. 1058-1059.

Asgharia, M., \& Aghdam, M.S. (2010). Impact of salicylic acid on post-harvest physiology of horticultural crops. Trends in Food Science and Technology, 21, 502-509.

Aghdam, M.S., Mostofi, Y., Motallebiazar, A., Ghasemneghad, M \& Fattahi Moghaddam J. (8-12 April 2009). Effects of MeSA vapor treatment on the postharvest quality of Hayward kiwifruit. In $6^{\text {th }}$ International Postharvest Symposium. Antalya, Turkey.

Asghari, M.R., Hajitagilo, R., \& Shirzad, H. (2007). Postharvest treatment of salicylic acid effectively controls pear fruit diseases and disorders during cold storage. COST action 924, proceedings of the international congress on Novel approaches for the control of postharvest diseases and disorders, 455-360.

Asghari, M.R., Hajitagilo, R., \& Jalilimarandi, R. (2009). Postharvest application of salicylic acid before coating with chitosan affects the pattern of quality changes in table grape during cold storage. In $6^{\text {th }}$ International Postharvest Symposium, Antalya, Turkey, 8-12 April 2009.

Babalar, M., Asghari, M., Talaei, A., \& Khosroshahi, A. (2007). Effect of pre- and postharvest salicylic acid treatment on ethylene production, fungal decay and overall quality of Selva strawberry fruit. Food Chem, 105, 449-453.

Cassano, A., Figoli, A., Tagarelli, A., Sindona, G., \& Drioli, E. (2006). Integrated membrane process for the production of highly nutritional kiwifruit juice. Desalination, 189, 21-30.

Cano Pilar, M. (1991). HPLC separation of chlorophyll and carotenoid pigments of four kiwi fruit cultivars. $J$ Agric Food Chem, 40, 594-598. 
Chance, B., \& Maehly, A.C. (1954). The assay of catalase and peroxidase. Methods of Biochemical Analysis, 1, $357-424$.

Chan, Z., \& Tian, S. (2006). Induction of $\mathrm{H}_{2} \mathrm{O}_{2}$ metabolizing enzyme and total protein synthesis by antagonistic yeast and salicylic acid in harvested sweet cherry fruit. Postharv Biol Technol, 39, 314-320.

Cordenunsi, R.R., \& Lajolo, F.M. (1995). Starch breakdown during banana ripening. Sucrose synthase and sucrose phosphate Synthase. J Agric Food Chem 43, 347-351.

Dempsey, D.A., Shah, J., \& Klessig, D.F. (1999). Salicylic acid and disease resistance in plants. Cri Rev Plant Scie, 18, 547-575.

Fan, X., Mattheis, J.P., \& Fellman, J.K. (1996). Inhibition of apple fruit 1-amino cyclopropane-1-carboxylic acid oxidase activity and respiration by acetyl salicylic acid. J Plant Physiol, 149, 469- 471.

Han, T., Wang, Y., Li, L., \& Ge, X. (2003). Effect of exogenous salicylic acid on postharvest physiology of peaches. Acta Hort, 628.

Hooper, L., \& Cassidy, A. (2006). A review of the health care potential of bioactive compounds. J. Sci. Food Agric, 86, 1805-1813.

Hubbard, N.L., Pharr, D.M., \& Huber, S.C. (1991). Sucrose phosphate synthase and other sucrose metabolizing enzymes in fruits of various species. Physiol Plant, 82, 191-196.

Hung, R. H., Liu, J. H., Lu, Y. M., \& Xia, R. X. (2007). Effect of salicylic acid on the antioxidant system in the pulp of Cara Cara navel orange (Citrus sinensis L. Osbeck) at different storage temperatures. Postharvest Biology and Technology, 47, 168-175.

Jimenez, A., Hernandez, J.A., del Rio, L.A., \& Sevilla, F. (1997). Evidence for the presence of the ascorbate-glutathione cycle in mitochondria and paroxysms of pea leaves. Plant Physiol, 114, 275-284.

Kang, G., Wang, C., Sun, G., \& Wang, Z. (2003). Salicylic acid changes activities of $\mathrm{H}_{2} \mathrm{O}_{2}$-metabolizing enzymes and increases the chilling tolerance of banana seedlings. Environ Expl Bot, 50, 9-15.

Lu, Y.Y., \& Chen, C.Y. (2005). Molecular analysis of lily leaves in response to salicylic acid effective towards protection against Botrytis elliptica. Plant Sci., 169, 1-9.

Leslie, C.A., \& Romani, R.J. (1986). Salicylic acid: a new inhibitor of ethylene biosynthesis. Plant Cell Rep, 5, 144-146.

Li, N., Parsons, B.L., Liu, D., \& Mattoo, A.K. (1992). Accumulation of wound- inducible ACC synthase transcript in tomato fruit is inhibited by salicylic acid and polyamines. Plant Mol Biol, 18, 477-487.

Srivastava, M.K., \& Dwivedi, U.N. (2000). Delayed ripening of banana fruit by salicylic acid. Plant Sci, 158, 87-96.

Langenkämper, G., McHale, R., Gardner, R.C., \& MacRae, E. (1998). Sucrose phosphate synthase steady-state mRNA increases in ripening kiwifruit. Plant Mol Biol, 36, 857-869.

Meena, B., Marimuthu, T., \& Velazhahan, R. (2001). Salicylic acid induces systemic resistance in groundnut against late leaf spot caused by Cercosporidium personatum. J Myco Plant Patho, 31, 139-145.

Qin, Q.Z., Tian, S.P., Xu, Y., \& Wan, Y.K. (2003). Enhancement of biocontrol efficacy of antagonistic yeasts by salicylic acid in sweet cherry fruit. Physiol Mol Plant Patho, 62,147-154.

Raskin, I. (1992). Salicylate, a new plant hormone. Plant Physiol, 99, 799-803.

Romani, R.J., Hess, B.M., \& Leslie, C.A. (1989). Salicylic acid inhibition of ethylene production by apple discs and other plant tissues. J Plant Growth Regul, 8, 63-69.

Shulaev, V., Silverman, P., \& Raskin, I. (1997). Airborne signaling by methyl salicylate in plant pathogen resistance. Nature, 385, 718-72.

Snowdon, A.L. (1990). Soft fruits and berry fruits, in A Color Atlas of Postharvest Diseases and Disorders of Fruits and Vegetables, ed. by Boca Raton, FL. CRC Press, pp. 238-252.

Wang, L.J., \& Li, S.H.H. (2006). Salicylic acid-induced heat or cold tolerance in relation to $\mathrm{Ca}^{2+}$ homeostasis and antioxidant systems in young grape plants. Plant Science, 170, 685-694.

Wang, L.J., Chen, S.J., Kun, W.F., Li, S.H., \& Archbold, D.D. (2006). Salicylic acid pretreatment alleviates chilling injury and affects the antioxidant system and heat shock proteins of peach during cold storage. Postharv Biol Technol, 41, 244-251. 
Wills, R., McGlasson, B., Graham, D., \& Joyce, D. (1998). Postharvest, an introduction to the physiology and handling of fruit and vegetables and ornamentals (4th Edn). Sydney 2052, Australia, University of New South Wales Press Ltd., University of New South Wales, pp. 125-156.

Wolucka, B.A., Goossens, A., \& Inze, D. (2005). Methyl Jasmonate stimulates the de novo biosynthesis of vitamin C in plant cell suspensions. J Exp Bot, 56, 2527-2538.

$\mathrm{Xu}, \mathrm{X} .$, \& Tian, S. (2008). Salicylic acid alleviated pathogen-induced oxidative stress in harvested sweet cherry fruit. Postharv Biol Technol, 49, 379-385.

Yao, H.J., \& Tian, S.P. (2005). Effects of pre- and postharvest application of SA or MeJA on inducing disease resistance of sweet cherry fruit in storage. Postharv Biol Technol, 35, 253-262.

Zeng, K.F., Cao, J.K., \& Jiang, W.B. (2006). Enhancing disease resistance in harvested mango (Mangifera indica L. cv. 'Matisu') fruit by salicylic acid. J Sci Food Agric, 86, 694-698.

Zhang, Y., Chen, K., Zhang, S., \& Ferguson, I. (2003). The role of salicylic acid in postharvest ripening of kiwifruit. Postharv Biol Technol, 28, 67-74.

Table 1. Effects of different combinations of MeSA concentrations and time of analysis on Hayward kiwifruit ethylene production $(\mathrm{nL} / \mathrm{Kg} / \mathrm{h})$

\begin{tabular}{|c|c|c|c|c|c|}
\hline \multirow[t]{2}{*}{ Quality attribute } & \multirow[t]{2}{*}{ Treatment } & \multicolumn{4}{|c|}{ Storage time (month) } \\
\hline & & 1 & 2 & 3 & 4 \\
\hline Ethylene & Control & $80.33 p$ & $126.66 \mathrm{k}$ & $138.66 \mathrm{~g}$ & $182 \mathrm{e}$ \\
\hline \multirow[t]{4}{*}{$(\mathrm{nL} / \mathrm{Kg} / \mathrm{h})$} & MeSA $8 \mu \mathrm{L} . \mathrm{L}$ & $71.66 \mathrm{q}$ & 102.331 & $126.66 \mathrm{i}$ & $164.33 \mathrm{~g}$ \\
\hline & MeSA $16 \mu \mathrm{L} . \mathrm{L}$ & $60.66 \mathrm{r}$ & $90.66 \mathrm{~m}$ & $112.66 \mathrm{j}$ & $151.66 \mathrm{~h}$ \\
\hline & MeSA $24 \mu \mathrm{L} . \mathrm{L}$ & $50.66 \mathrm{~s}$ & $79.66 n$ & $100 \mathrm{k}$ & $145.33 \mathrm{i}$ \\
\hline & MeSA32 $\mu{\mathrm{L} . \mathrm{L}^{1}}^{1}$ & $42.66 \mathrm{t}$ & 530 & $87.66 \mathrm{n}$ & $132.33 \mathrm{j}$ \\
\hline
\end{tabular}

Means with the same letter in a column are not significantly different at $P<0.01$ (Duncan's test).

Table 2. Effects of different combinations of MeSA concentrations and time of analysis on Hayward kiwifruit fruit firmness $(\mathrm{N})$, vitamin $\mathrm{C}(\mathrm{mgr} / 100 \mathrm{gr} \mathrm{FW})$ content and weight loss (gr)

\begin{tabular}{|c|c|c|c|c|c|c|}
\hline \multirow[t]{2}{*}{ Quality attribute } & \multirow[t]{2}{*}{ Treatment } & \multicolumn{5}{|c|}{ Storage time (month) } \\
\hline & & 1 & 2 & 3 & 4 & 5 \\
\hline Firmness & Control & $5.5 \mathrm{e}$ & $3.5 \mathrm{k}$ & $2.4 \mathrm{mno}$ & $1.8 \mathrm{q}$ & 1.031 \\
\hline \multirow[t]{4}{*}{$(\mathrm{N})$} & MeSA $8 \mu{\mathrm{L} . \mathrm{L}^{-1}}^{-1}$ & $5.9 \mathrm{~d}$ & 3.9hi & $2.6 \mathrm{~m}$ & $1.8 \mathrm{q}$ & $1.2 \mathrm{~s}$ \\
\hline & MeSA $16 \mu{\mathrm{L} . \mathrm{L}^{-1}}^{-1}$ & $6.2 \mathrm{c}$ & $4.2 \mathrm{~g}$ & 3.11 & $2.2 \mathrm{p}$ & $1.5 \mathrm{r}$ \\
\hline & MeSA $24 \mu{\mathrm{L} . \mathrm{L}^{-1}}^{-1}$ & $6.5 b$ & $4.9 \mathrm{f}$ & $3.8 \mathrm{i}$ & $2.5 \mathrm{~m}$ & $2.4 \mathrm{mn}$ \\
\hline & MeSA $32 \mu{\mathrm{L} . \mathrm{L}^{-1}}^{-1}$ & $7 \mathrm{a}$ & $5.5 \mathrm{e}$ & $4.3 \mathrm{~g}$ & 3.21 & 2.20 \\
\hline Vitamin $\mathrm{C}$ & Control & $60 \mathrm{~g}$ & $55 \mathrm{jk}$ & $49.3 \mathrm{~m}$ & $44.6 n$ & 410 \\
\hline \multirow[t]{4}{*}{$(\mathrm{mgr} / 100 \mathrm{gr} \mathrm{FW})$} & MeSA $8 \mu \mathrm{L} . L^{-1}$ & $63 \mathrm{e}$ & $60.3 \mathrm{fg}$ & $56 \mathrm{ij}$ & 511 & $46 n$ \\
\hline & MeSA $16 \mu{\mathrm{L} . \mathrm{L}^{-1}}^{-1}$ & $67 d$ & $62.6 \mathrm{e}$ & $60.3 \mathrm{fg}$ & $55 \mathrm{jk}$ & $501 \mathrm{~m}$ \\
\hline & MeSA $24 \mu{\mathrm{L} . \mathrm{L}^{-1}}^{-1}$ & $71 \mathrm{~b}$ & $65.6 \mathrm{~d}$ & $61.6 \mathrm{ef}$ & 56.6hi & $53.6 \mathrm{k}$ \\
\hline & MeSA $32 \mu{\mathrm{L} . \mathrm{L}^{-1}}^{-1}$ & $75 a$ & $69 \mathrm{c}$ & $65.6 \mathrm{~d}$ & $61 \mathrm{fg}$ & $58 \mathrm{~h}$ \\
\hline Weigh loss & Control & $1.5 n$ & $2 \mathrm{k}$ & $2.8 \mathrm{~h}$ & $3.8 \mathrm{e}$ & $6.7 \mathrm{a}$ \\
\hline \multirow[t]{4}{*}{ (g) } & MeSA $8 \mu{\mathrm{L} . \mathrm{L}^{-1}}^{-1}$ & $1.4 \mathrm{o}$ & 1.81 & $2.5 \mathrm{i}$ & $3.5 \mathrm{f}$ & $5.3 \mathrm{~b}$ \\
\hline & MeSA $16 \mu{\mathrm{L} . \mathrm{L}^{-1}}^{-1}$ & $1.2 \mathrm{p}$ & $1.5 \mathrm{mn}$ & $2.1 \mathrm{jk}$ & $2.9 \mathrm{~g}$ & $4.6 \mathrm{c}$ \\
\hline & MeSA $24 \mu{\mathrm{L} . \mathrm{L}^{-1}}^{-1}$ & $1.1 \mathrm{q}$ & $1.4 \mathrm{o}$ & 1.81 & $2.6 \mathrm{i}$ & $4 d$ \\
\hline & MeSA $32 \mu{\mathrm{L} . \mathrm{L}^{-1}}^{-1}$ & $1 \mathrm{r}$ & $1.3 \mathrm{p}$ & $1.6 \mathrm{~m}$ & $2.1 \mathrm{j}$ & $3.5 \mathrm{f}$ \\
\hline
\end{tabular}

Means with the same letter in a column are not significantly different at $P<0.01$ (Duncan's test). 
Table 3. Effects of MeSA concentration on Hayward kiwifruit TSS, pH, DI \% and TSS/TA

\begin{tabular}{|c|c|c|c|c|c|}
\hline \multirow{2}{*}{$\begin{array}{c}\text { Quality } \\
\text { attribute }\end{array}$} & \multicolumn{3}{|c|}{ Treatment (MeSA $\left.\mu \mathrm{L}^{1}\right)$} & \\
\cline { 2 - 6 } & Control & 8 & 16 & 24 & 32 \\
\hline $\mathrm{TSS}$ & $14.7 \mathrm{~b}$ & $14.39 \mathrm{~b}$ & $14.39 \mathrm{~b}$ & $13.84 \mathrm{a}$ & $13.70 \mathrm{a}$ \\
\hline $\mathrm{pH}$ & $3.52 \mathrm{bc}$ & $3.48 \mathrm{~b}$ & $3.45 \mathrm{ab}$ & $3.40 \mathrm{a}$ & $3.45 \mathrm{ab}$ \\
\hline $\mathrm{DI} \%$ & $34.3 \mathrm{e}$ & $28 \mathrm{~d}$ & $20.6 \mathrm{c}$ & $13.3 \mathrm{~b}$ & $6.3 \mathrm{a}$ \\
\hline TSS/TA & $20.06 \mathrm{~b}$ & $19.84 \mathrm{~b}$ & $19.67 \mathrm{~b}$ & $17.89 \mathrm{a}$ & $19.53 \mathrm{~b}$ \\
\hline
\end{tabular}

Means with the same letter in a column are not significantly different at $P<0.05$ (Duncan's test).

Table 4. Effects of different combinations of MeSA concentrations and time of analysis on CAT and APX activity in Hayward kiwifruit

\begin{tabular}{|c|c|c|c|c|}
\hline \multirow[t]{2}{*}{ Quality attribute } & \multirow[t]{2}{*}{ Treatment } & \multicolumn{3}{|c|}{ Storage time (month) } \\
\hline & & 1 & 3 & 5 \\
\hline \multirow[t]{5}{*}{ APX activity } & Control & $0.035 f$ & $0.044 \mathrm{c}$ & $0.057 \mathrm{a}$ \\
\hline & MeSA $8 \mu{\mathrm{L} . \mathrm{L}^{-1}}^{-1}$ & $0.03 \mathrm{~h}$ & $0.038 \mathrm{c}$ & $0.050 \mathrm{~b}$ \\
\hline & MeSA $16 \mu{\mathrm{L} . \mathrm{L}^{-1}}^{-1}$ & $0.025 \mathrm{i}$ & $0.029 \mathrm{~h}$ & $0.041 \mathrm{~d}$ \\
\hline & MeSA $24 \mu{\mathrm{L} . \mathrm{L}^{-1}}^{-1}$ & $0.02 \mathrm{j}$ & $0.025 \mathrm{i}$ & $0.032 \mathrm{~g}$ \\
\hline & MeSA $32 \mu{\mathrm{L} . \mathrm{L}^{-1}}^{-1}$ & $0.015 \mathrm{k}$ & $0.018 \mathrm{j}$ & $0.025 \mathrm{i}$ \\
\hline \multirow[t]{5}{*}{ CAT activity } & Control & $0.076 \mathrm{ed}$ & $0.090 \mathrm{c}$ & $0.12 \mathrm{a}$ \\
\hline & MeSA $8 \mu{\mathrm{L} . \mathrm{L}^{-1}}^{-1}$ & $0.065 f$ & $0.079 \mathrm{~d}$ & $0.10 \mathrm{~b}$ \\
\hline & MeSA $16 \mu{\mathrm{L} . \mathrm{L}^{-1}}^{-1}$ & $0.054 \mathrm{~g}$ & $0.065 \mathrm{f}$ & $0.08 \mathrm{c}$ \\
\hline & MeSA $24 \mu \mathrm{L} . \mathrm{L}^{-1}$ & $0.040 \mathrm{~h}$ & $0.055 \mathrm{~g}$ & $0.073 \mathrm{e}$ \\
\hline & MeSA $32 \mu{\mathrm{L} . \mathrm{L}^{-1}}^{-1}$ & $0.033 \mathrm{i}$ & $0.043 \mathrm{~h}$ & $0.061 \mathrm{f}$ \\
\hline
\end{tabular}

Means with the same letter in a column are not significantly different at $P<0.01$ (Duncan's test). 